February 2005 - NREL/CP-520-37378

\title{
$p$-Type ZnO Thin Films Grown by MOCVD
}

X. Li, S.E. Asher, B.M. Keyes, H.R. Moutinho, J. Luther, and T.J. Coutts

Prepared for the $31^{\text {st }}$ IEEE Photovoltaics Specialists Conference and Exhibition

Lake Buena Vista, Florida

January 3-7, 2005
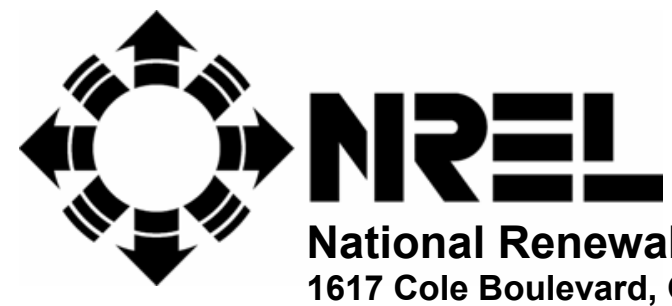

National Renewable Energy Laboratory 1617 Cole Boulevard, Golden, Colorado 80401-3393 303-275-3000 • www.nrel.gov

Operated for the U.S. Department of Energy

Office of Energy Efficiency and Renewable Energy

by Midwest Research Institute $\bullet$ Battelle

Contract No. DE-AC36-99-G010337 


\section{NOTICE}

The submitted manuscript has been offered by an employee of the Midwest Research Institute (MRI), a contractor of the US Government under Contract No. DE-AC36-99G010337. Accordingly, the US Government and MRI retain a nonexclusive royalty-free license to publish or reproduce the published form of this contribution, or allow others to do so, for US Government purposes.

This report was prepared as an account of work sponsored by an agency of the United States government. Neither the United States government nor any agency thereof, nor any of their employees, makes any warranty, express or implied, or assumes any legal liability or responsibility for the accuracy, completeness, or usefulness of any information, apparatus, product, or process disclosed, or represents that its use would not infringe privately owned rights. Reference herein to any specific commercial product, process, or service by trade name, trademark, manufacturer, or otherwise does not necessarily constitute or imply its endorsement, recommendation, or favoring by the United States government or any agency thereof. The views and opinions of authors expressed herein do not necessarily state or reflect those of the United States government or any agency thereof.

Available electronically at http://www.osti.gov/bridge

Available for a processing fee to U.S. Department of Energy and its contractors, in paper, from:

U.S. Department of Energy

Office of Scientific and Technical Information

P.O. Box 62

Oak Ridge, TN 37831-0062

phone: 865.576 .8401

fax: 865.576.5728

email: mailto:reports@adonis.osti.gov

Available for sale to the public, in paper, from:

U.S. Department of Commerce

National Technical Information Service

5285 Port Royal Road

Springfield, VA 22161

phone: 800.553 .6847

fax: 703.605.6900

email: orders@ntis.fedworld.gov

online ordering: http://www.ntis.gov/ordering.htm 


\title{
$p$-TYPE ZnO THIN FILMS GROWN BY MOCVD
}

\author{
X. Li, S.E. Asher, B.M. Keyes, H.R. Moutinho, J. Luther, \\ and T. J. Coutts \\ National Renewable Energy Laboratory, 1617 Cole Boulevard, Golden, CO 80401
}

\begin{abstract}
$\mathrm{ZnO}$ has demonstrated a possibility to be doped as a $p$-type by using nitrogen and other group- $\mathrm{V}$ elements. A high nitrogen doping concentration by metalorganic chemical vapor deposition (MOCVD) with nitric oxide (NO) gas has been achieved. However, the processing window for obtaining the $p$-type $\mathrm{ZnO}: \mathrm{N}$ film is very narrow, and the hole concentration is typically low. Possible compensation and passivation effects have been studied. Hydrogen and carbon elements are detected by secondary-ion mass spectroscopy (SIMS). Considering the other experimental and modeling results, we believe that the impurities inadvertently incorporated with the zinc precursor could be compensating or passivating the nitrogen acceptor and result in the low hole concentration.
\end{abstract}

\section{INTRODUCTION}

$\mathrm{ZnO}$, a wide-bandgap semiconductor material, is widely used in various applications. It can be easily doped to $n$-type, but is difficult to dope to $p$-type [1]. Low impurity solubility, excessive accepter ionization energy, and possible compensating mechanisms are the three main factors that could make $p$-type doping of $\mathrm{ZnO}$ difficult. In addition to being of interest for ultraviolet light emitters, $p$-type $\mathrm{ZnO}$ has a potential advantage in the fabrication of novel solar cell structures: inverted CdTe devices, improved contacts to both $p$-type absorbers, and organic semiconductors. The recent reports on $p$-type $\mathrm{ZnO}$ brings this potential close to reality [29].

In this report, we discuss the achievement and the issues that have been observed on the nitrogen-doped $p$-type $\mathrm{ZnO}$ films formed by MOCVD. Special focus is put on the low hole concentration and possible compensation mechanisms.

\section{EXPERIMENTAL}

$P$-type $\mathrm{ZnO}$ films have been fabricated by MOCVD, using diethylzinc (DEZn) and nitric oxide (NO) precursors. NO gas serves as both the oxidizer and nitrogen dopant in this reaction. The substrate is Corning 1737 glass. More information on $\mathrm{ZnO}: \mathrm{N}$ sample fabrication can be found in previous papers [10].

The composition of the $\mathrm{ZnO}$ films was analyzed by a CAMECA IMS 5f SIMS. Film topography was taken by atomic force microscopy (AFM, Auto probe LS from Park Scientific Instruments with $\mathrm{Si}$ Cantilevers). Electrical and optical properties were measured using Hall analysis (BioRad Model HL5500), capacitancevoltage (double-Schottky surface contact with mercury probe), and a Cary 5G spectrophotometer.

\section{RESULTS AND DISCUSSION}

The MOCVD-formed $\mathrm{ZnO}: \mathrm{N}$ films on glass substrate are randomly oriented polycrystalline with a light yellow color. The 
transparent spectra of the $\mathrm{ZnO}: \mathrm{N}$ compare with the $\mathrm{ZnO}$ film shown in Fig. 1. The increased absorption around the band edge of the $\mathrm{ZnO}: \mathrm{N}$ made the film look yellow. The topography of the $\mathrm{ZnO}: \mathrm{N}$ on glass substrate is illustrated in Fig. 2.

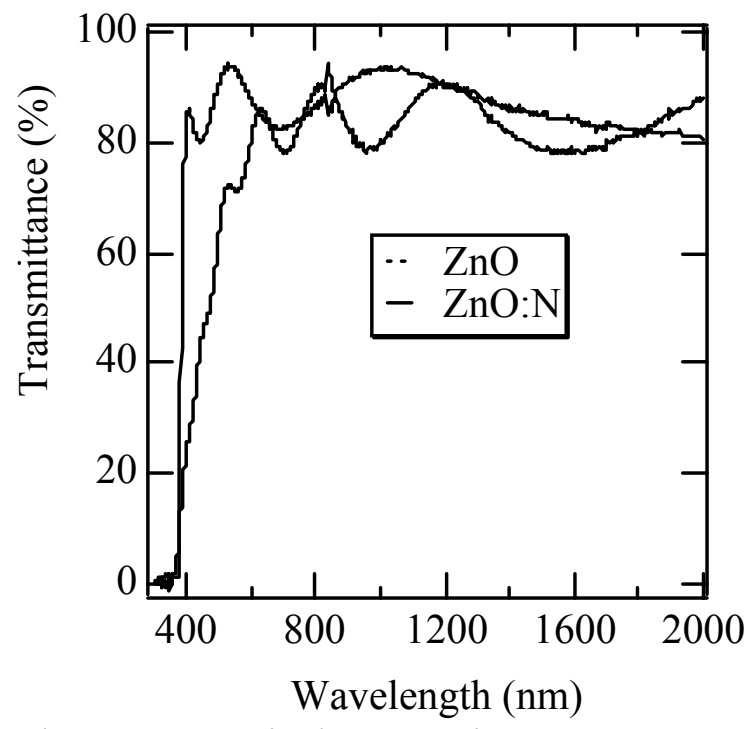

Figure 1. Optical transmittance spectra of $\mathrm{ZnO}$ and $\mathrm{ZnO}: \mathrm{N}$ films.

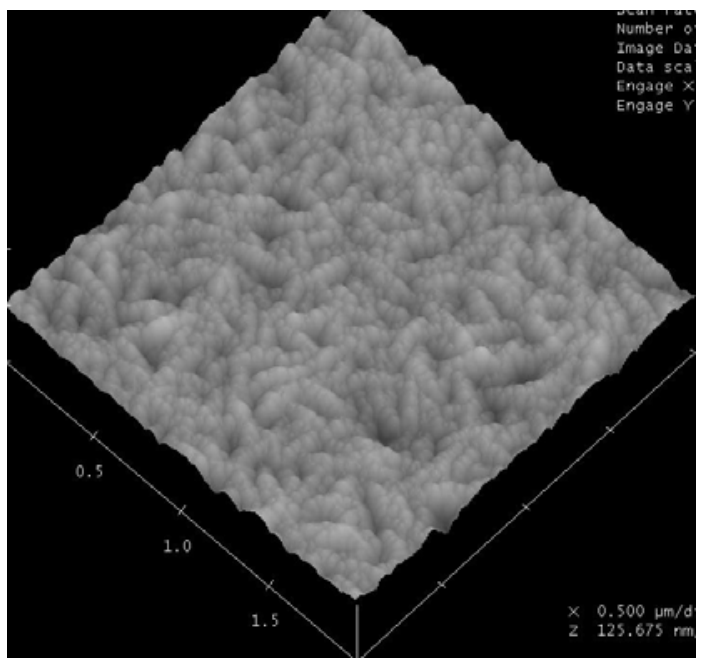

Figure. 2. The topography of a $0.74-\mu \mathrm{m}-$ thick $\mathrm{ZnO}: \mathrm{N}$ film grown on a glass substrate.

An O-poor growth ambient is required for nitrogen doping. Therefore, all the $\mathrm{ZnO}: \mathrm{N}$ films studied here were formed with $\mathrm{NO}$ gas as the oxidizer. When NO gas is the only oxidizer, nitrogen concentration levels in the range of $1.75 \times 10^{21} \sim 2.60 \times 10^{21} \mathrm{~cm}^{-3}$ have been achieved. The high nitrogen concentration level can be achieved in a wide processing range, but the growth window for fabricating the $p$-type $\mathrm{ZnO}: \mathrm{N}$ is narrow. The $p$-type films are observed only in a temperature range of $400^{\circ}-440^{\circ} \mathrm{C}$ [10]. Although some of the $\mathrm{ZnO}: \mathrm{N}$ films deposited in this temperature range are remain insulating.

Results of Hall probe analysis of several $\mathrm{ZnO}$ samples are shown in Table 1. Undoped $\mathrm{ZnO}$ is $n$-type with a carrier concentration in the range of $10^{16} \sim 10^{18} \mathrm{~cm}^{-3}$. The nitrogen-doped $\mathrm{ZnO}$ samples are no long $n$-type but are insulator or weak $p$-type. The hole concentration is around $10^{13}$ to $10^{18} \mathrm{~cm}^{-3}$ and the resistivity is in the range of 2 to few hundred $\Omega-\mathrm{cm}$. The capacitance-voltage (C$\mathrm{V})$ technique was used to confirm the Hall results. Without post-deposition heat treatment, the $\mathrm{C}-\mathrm{V}$ analysis indicated that the as-deposited $\mathrm{ZnO}: \mathrm{N}$ sample is weak $p$-type.

Table 1. Electrical properties of $\mathrm{ZnO}$ films deposited at a temperature of $400^{\circ} \mathrm{C}$.

\begin{tabular}{|r|c|r|r|}
\hline Doping & $\begin{array}{c}\text { C. C. } \\
\left(\mathrm{cm}^{-3}\right)\end{array}$ & $\begin{array}{c}\mu \\
\left(\mathrm{cm}^{2} / \mathrm{V}\right)\end{array}$ & $\begin{array}{c}\rho \\
(\Omega-\mathrm{cm})\end{array}$ \\
\hline $\mathrm{ZnO}$ & $-8.42 \times 10^{18}$ & 3.2 & 0.235 \\
\hline $\mathrm{ZnO}$ & $-8.38 \times 10^{16}$ & 6.3 & 11.8 \\
\hline $\mathrm{ZnO}: \mathrm{N}$ & $9.24 \times 10^{13}$ & 236 & 286 \\
\hline $\mathrm{ZnO}: \mathrm{N}$ & $8.36 \times 10^{17}$ & 4.55 & 1.64 \\
\hline
\end{tabular}

The measured carrier concentration is several orders of magnitude lower than the nitrogen concentration. With the achieved nitrogen doping concentrations, it is clear that the limitation is not due to the dopant solubility. Several other reasons could be: (1) a small fraction of the nitrogen acts as an acceptor. There is a possibility that the nitrogen forming the $\left[\left(\mathrm{N}_{2}\right)_{\mathrm{O}}\right]$ (two nitrogen atoms substitute on an oxygen site) double shallow donor instead of $\left(\mathrm{N}_{\mathrm{O}}\right)$ single deep acceptor [11]. (2) The nitrogen acceptors' energy levels lie well above the valence band 
edge. And (3), a strong compensation or passivation mechanism exists. The second possibility has been discussed previously [10]. The calculations indicated that the ionization energy needs to be as much as $\sim 350 \mathrm{meV}$ to explain the observed difference between the nitrogen and the carrier concentration. Considering the recent experimental result that the ionization energy $\mathrm{N}_{\mathrm{O}}$ is about $160 \mathrm{meV}$, a much larger carrier concentration should result [12]. With the knowledge of the possible impurities introduced by MOCVD procedures, in this study, we shall focus our attention on the third possibility: compensation or passivation effects by possible impurities introduced during MOCVD deposition.

The depth profiles of hydrogen and carbon in $\mathrm{ZnO}: \mathrm{N}$ films were obtained using SIMS. In both $\mathrm{ZnO}$ and $\mathrm{ZnO}: \mathrm{N}$ films, both hydrogen and carbon have been found. Figure 3 indicates hydrogen and carbon concentrations are strongly affected by deposition temperature. This observation indicates that the hydrogen and carbon elements are possibly introduced as the products of the zinc precursor $\left(\left(\mathrm{C}_{2} \mathrm{H}_{5}\right)_{2} \mathrm{Zn}\right)$ decomposition process.

It has been found that the other zinc metal-organic precursor $\left(\left(\mathrm{CH}_{3}\right)_{2} \mathrm{Zn}\right)$ introduced some carbon into the $\mathrm{ZnO}$ film [13]. There are not many studies on the function of the carbon in $\mathrm{ZnO}$ film. In nitrogen-doped $\mathrm{ZnO}$, there is evidence that carbon has possibly bonded with nitrogen [14]. The recent theoretical study conducted at NREL indicated that the carbon-related defect in $\mathrm{ZnO}: \mathrm{N}$ film most possible are donor type. Thus, the carbon is an undesirable impurity for $p$-type $\mathrm{ZnO}$ film [15].

The role of hydrogen in $\mathrm{ZnO}$ has been well studied [16-18]. It has been indicated that hydrogen acts only as a donor in $\mathrm{ZnO}$. There are not many studies on the function of hydrogen in a nitrogen-doped $\mathrm{ZnO}$ film. Considering the difficulty associated with nitrogen doping by MOCVD and the high level of hydrogen concentration in the $\mathrm{ZnO}$ film, we believe that hydrogen could be one of the important factors in determining the efficiency of nitrogen doping.

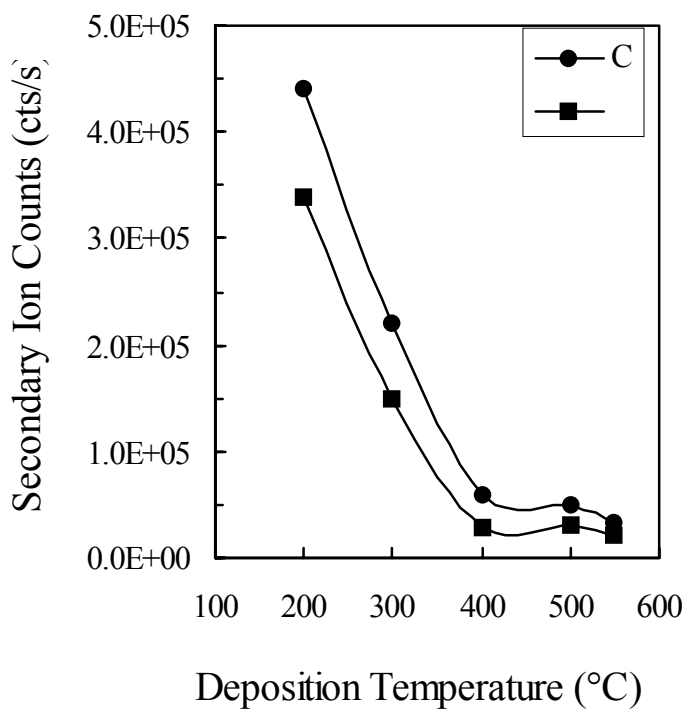

Figure 3: The hydrogen and carbon impurity levels varied with deposition temperature in MOCVD-formed $\mathrm{ZnO}$ films.

Our study by Fourier transform infrared spectroscopy (FTIR) and firstprinciples calculations indicated that there is a strong tendency for $\mathrm{N}_{\mathrm{O}}^{-}$and $\mathrm{H}^{+}$defects to form a neutral combined defect complex [19]. In undoped $\mathrm{ZnO}$ samples, hydrogen bonded with oxygen. With nitrogen doping, the intensity of the absorption peak due to O$\mathrm{H}$ decreased, and the absorption line at 3007 $\mathrm{cm}^{-1}$ due to the $\mathrm{N}_{\mathrm{O}}-\mathrm{H}$ (anti-bonding) emerged. This observation implies that one of the possible reasons for low hole concentration in heavily doped $\mathrm{ZnO}: \mathrm{N}$ is due to the hydrogen passivation effect.

In summary, we have fabricated $p$ type, nitrogen-doped $\mathrm{ZnO}$ by MOCVD. The nitrogen concentration achieved using this method is as high as $2.60 \times 10^{21} \mathrm{~cm}^{-3}$. However, low hole concentration is observed. Hydrogen and carbon elements have been detected by SIMS analysis. This, together 
with FTIR, XPS, and modeling results, provides strong evidence that compensation or passivation of nitrogen acceptors by inadvertently incorporated impurities exist in $\mathrm{ZnO}: \mathrm{N}$ films, thereby resulting in the low hole concentration.

\section{ACKNOWLEDGEMENTS}

The authors would like to acknowledge James Keane for sample preparation and Matthew Young for SIMS characterization. This work was supported by the U.S. Department of Energy under Contract No. DE-AC36-99GO10337.

\section{REFERENCES:}

1. S.B. Zhang, S.-H. Wei, and A. Zunger, J. Appl. Phys., 83, 3192 (1998).

2. Kazunori Minegishi, Yasushi Koiwai, Kikuchi, Koji Yano, Masanobu Kasuga, Japan Journal of Applied Physics, 36, L1453, (1997)

3. Mathew Joseph, Hitoshi Tabata, and Tomoji Kawai, J. JAP 38 L1205, (1999)

4. Y.R. Ryu, S. Zhu, D.C. Look, J.M. Wrobel, H.M. Jeong, H.W. White, Journal of Crystal Growth 216330 (2000)

5. X. Li, Y . Yan, T.A. Gessert, C. Dehart, C.L. Perkins, D. Young, and T.J. Coutts, Electrochemical and Solid Letters, 6(4) C56C58 (2003).

6. Xin-Li Guo, Hitoshi Tabata, Tomoji Kawai, Journal of Crystal Growth, 223 , 135 (2001).
7. T. Aoki, Y. Shimizu, A. Miyake, A. Nakamura, Y. Nakanishi, and Y. Hatanaka, Phys. Stat. Sol. (b) 229, 911, (2002)

8. A.B.M. Almamum Ashrafi, Ikuo Suemune, Hidekazu Kumano, and Satoru Tanaka, Japan Journal of Applied Physics, 41, L1281. (2002)

9. B.S. Li, Y.C. Liu, Z.Z. Zhi, D.Z. Shen, Y.M. Lu, J.Y. Zhang, X.W. Fan, R.X. Mu, and Don O. Henderson, J. Mater. Res. 18, 9 (2003).

10. X. Li, Y . Yan, T.A. Gessert, C.L. Perkins, D. Young, C. Dehart, and T.J. Coutts, J. Vac. Sci. Technol. A21, 1342, (2003).

11. Yanfa Yan and S.B. Zhang, Physical Review Letters, 86, 5723, (2001).

12. B.K. Meyer, H. Alves, D.M. Hofmann, W. Kriegseis, D. Forster, F. Bertram, J. Chresten, A. Hoffmann, M. Strabburg, M. Dworzak, U. Haboeck, and A.V. Rodina, Phys. Stat. Sol. (b) 241, 231, (2004)

13. Teresa M. Barnes, Steve Hand, Jackie Leaf, and Colin A. Wolden, J. Vac. Sci. Technol. A22, 2118.

14. C.L. Perkins, S.-H. Lee, X. Li, S.E. Asher, and T.J. Coutts, Journal of Applied Physics, (submitted).

15. S. Limpijumnong, X. Li, S-H. Wei, S.B. Zhang, (submitted).

16. Chris G. Van De Walle, Phys. Stat. Sol (b) 229, 221 (2002).

17. E.V. Lavrov, J. Weber, and F. Borrnert, Physical Review B 66, 165205, (2002).

18. C. H. Seager and S.M. Myers, Journal of Applied Physics, 94, 2888, (2003).

19. X. Li, S. Limpijumnong B.M. Keyes, S.E. Asher, S.B. Zhang, S-H. Wei, C.G. Van de Walle, and T.J. Coutts (submitted). 


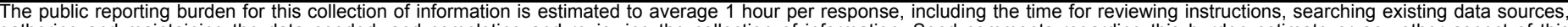

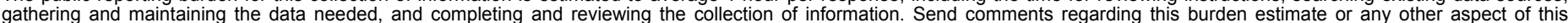

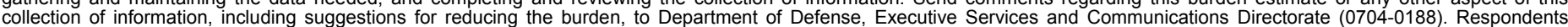

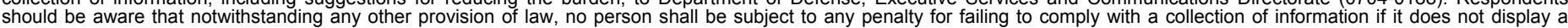

should be aware that notwithstanding

PLEASE DO NOT RETURN YOUR FORM TO THE ABOVE ORGANIZATION.

\section{REPORT DATE (DD-MM-YYYY) \\ February 2005 \\ 2. REPORT TYPE
Conference Paper}

4. TITLE AND SUBTITLE

p-Type ZnO Thin Films Grown by MOCVD
3. DATES COVERED (From - To)

3-7 January 2005

5a. CONTRACT NUMBER

DE-AC36-99-GO10337

5b. GRANT NUMBER

5c. PROGRAM ELEMENT NUMBER

5d. PROJECT NUMBER

NREL/CP-520-37378

5e. TASK NUMBER

PVA54301

5f. WORK UNIT NUMBER
7. PERFORMING ORGANIZATION NAME(S) AND ADDRESS(ES)

National Renewable Energy Laboratory

1617 Cole Blvd.

Golden, CO 80401-3393
8. PERFORMING ORGANIZATION REPORT NUMBER

NREL/CP-520-37378

9. SPONSORING/MONITORING AGENCY NAME(S) AND ADDRESS(ES)

10. SPONSOR/MONITOR'S ACRONYM(S) NREL

11. SPONSORING/MONITORING AGENCY REPORT NUMBER

12. DISTRIBUTION AVAILABILITY STATEMENT

National Technical Information Service

U.S. Department of Commerce

5285 Port Royal Road

Springfield, VA 22161

13. SUPPLEMENTARY NOTES

14. ABSTRACT (Maximum 200 Words)

$\mathrm{ZnO}$ has demonstrated a possibility to be doped as a $p$-type by using nitrogen and other group- $\mathrm{V}$ elements. A high nitrogen doping concentration by metalorganic chemical vapor deposition (MOCVD) with nitric oxide (NO) gas has been achieved. However, the processing window for obtaining the $p$-type $\mathrm{ZnO}: \mathrm{N}$ film is very narrow, and the hole concentration is typically low. Possible compensation and passivation effects have been studied. Hydrogen and carbon elements are detected by secondary-ion mass spectroscopy (SIMS). Considering the other experimental and modeling results, we believe that the impurities inadvertently incorporated with the zinc precursor could be compensating or passivating the nitrogen acceptor and result in the low hole concentration.

\section{SUBJECT TERMS}

PV; thin films; p-type; nitrogen doping; metalorganic chemical vapor deposition (MOCVD); nitric oxide (NO); secondary-ion mass spectroscopy (SIMS);

\begin{tabular}{|c|c|c|c|c|c|}
\hline 16. SECURITY & CLASSIFICATI & N OF: & 17. LIMITATION & 18. NUMBER & 19a. NAME OF RESPONSIBLE PERSON \\
\hline a. REPORT & b. ABSTRACT & c. THIS PAGE & OF ABSTRACT & & \\
\hline Unclassified & & & & & 19b. TELEPHONE NUMBER (Include area code) \\
\hline
\end{tabular}

